\title{
HUBUNGAN ANTARA KOMUNIKASI INTERPERSONAL DALAM KELUARGA DENGAN KENAKALAN REMAJA
}

Jurnal Pendidikan Luar Sekolah

http://kolokium.ppj.unp.ac.id/ Jurusan Pendidikan Luar Sekolah

Fakultas Ilmu Pendidikan

Universitas Negeri Padang

Sumatera Barat, Indonesia

Volume 5, Nomor 2, Oktober 2017 DOI: $10.24036 /$ kolokium-pls.v5i2.32

\author{
Amalia ${ }^{1,2}$, MHD. Natsir ${ }^{1}$ \\ 1Jurusan Pendidikan Luar Sekolah Fakultas Ilmu Pendidikan Universitas Negeri Padang \\ 2Email: mhdnatsir_yunas@fip.unp.ac.id
}

\begin{abstract}
ABSTRAK
Penelitian ini dilatarbelakangi oleh tingginya tingkat kenakalan remaja. Kenakalan remaja dapat mempengaruhi banyak faktor, salah satunya adalah kurangnya aplikasi komunikasi interpersonal keluarga. Diperkirakan ada hubungannya dengan komunikasi interpersonal dalam family. Penelitian ini untuk mendeskripsikan komunikasi interpersonal remaja pada keluarga, menggambarkan kenakalan, dan hubungan antara komunikasi interpersonal dalam keluarga dengan kenakalan remaja di Kampung Cimpu. Penelitian ini adalah tipe korelasional kuantitatif dengan 30 subjek penelitian yang sedang dipelajari siswa di SMAN 1 Sutera. Hasil penelitian ini dapat menunjukkan bahwa ada hubungan yang signifikan antara komunikasi interpersonal dalam keluarga dengan kenakalan remaja.
\end{abstract}

Kata Kunci: Komunikasi Antarpribadi, Kenakalan Remaja

\section{PENDAHULUAN}

Keluarga merupakan tempat pertama seorang anak belajar mengenai norma-norma, agama, maupun proses sosial, sehingga komunikasi yang efektif perlu diciptakan agar dapat membangun hubungan yang harmonis antara orang tua dan anak. Orang tua memiliki peran penting dalam proses pendidikan anak. Anak menjadikan orang tua sebagai figur utama yang dapat dijadikan contoh dalam menjalani berbagai persoalan dalam kehidupan, khususnya dalam pendidikan yang lebih baik. Namun, ketika terjadi persoalan antara anak dengan orang tua, maka sangat dimungkinkan akan memunculkan berbagai persoalan, di antaranya adalah kenakalan remaja.

Kenakalan remaja salah satunya dipengaruhi oleh faktor keluarga. Gaya komunikasi orang tua terhadap remaja yang kurang baik justru dapat mengakibatkan kenakalan remaja. Kenakalan remaja dewasa ini sudah menjadi program pemerintah untuk menanggulanginya. Hal ini sudah terbukti sejak tahun 1971 Pemerintah telah menaruh perhatian yang serius dengan dikeluarkannya Bakolak Inpres No. 6/ 1971 Pedoman 8 dalam Willis (2008) tentang Pola Penanggulangan Kenakalan Remaja. Di dalam pedoman itu diungkapkan mengenai pengertian kenakalan remaja ialah kelainan tingkah laku, perbuatan, atau tindakan remaja yang bersifat asosial, bahkan anti sosial yang melanggar normanorma sosial, agama serta ketentuan hukum yang berlaku di dalam masyarakat. 
Menurut Hurlock dalam Willis (2008) kenakalan anak dan remaja bersumber dari moral yang sudah berbahaya atau beresiko (moral hazard). Menurutnya, kerusakan moral katanya bersumber dari (1) keluarga yang sibuk, keluarga yang retak dan keluarga dengan single parent dimana anak hanya diasuh oleh ibu, (2) menurunnya kewibawaan sekolah dalam mengawasi anak, dan (3) peranan agama tidak mampu menangani masalah moral.

Konflik-konflik yang berkembang antara orang tua dan remaja menjadi berlarutlarut, dapat menimbulkan berbagai hal yang negatif baik bagi remaja itu sendiri maupun dalam hubungannya antara sesa ma remaja dan orang tuanya. Kondisi demikian merupakan suatu keadaan yang tidak baik bagi remaja yang dapat menimbulkan berbagai permasalahan yang kompleks, baik fisik maupun sosial—-termasuk pendidikan. Dalam hal fisik, antara lain dapat menimbulkan keluhan fisik yang tidak jelas penyebabnya maupun berbagai permasalahan yang berdampak pada perilaku anti sosial yang sering terjadi pada remaja seperti terlambat masuk sekolah, membolos, tawuran, mencuri, dan merokok di sekolahlebih parah lagi menyalahgunakan NAPZA (Wardyaningrum, 2013)

Hubungan yang terjalin antara orang tua dan anak adalah bersifat dua arah, disertai dengan pemahaman bersama terhadap sesuatu hal, di mana antara orang tua dan anak berhak menyampaikan pendapat, pikiran, informasi atau nasehat. Menurut Walgito (2004), di samping keterbukaan dalam komunikasi, komunikasi di dalam keluarga sebaiknya merupakan komunikasi dua arah, yaitu saling memberi dan saling menerima di antara anggota keluarga. Dengan komunikasi dua arah akan terdapat umpan balik, masingmasing pihak aktif, dan dapat memberikan pendapatnya mengenai masalah yang dikomunikasikan, sehingga terciptalah komunikasi yang dinamis (Mariska, 2014).

Komunikasi dalam keluarga memiliki peran yang sangat penting, khususnya antara orang tua dan anak. Komunikasi adalah hal yang penting dalam hidup, karena tanpa komunikasi manusia tidak akan pernah tahu apa yang terjadi di dunia dalam maupun luar bahkan tidak pernah mengetahui seperti apa dirinya atau orang lain jika tidak ada komunikasi antara satu dengan yang lain. Komunikasi adalah sebuah pesan yang disampaikan kepada seseorang dengan maksud dan tujuan. Komunikasi juga bisa sebagai sebuah interaksi, yaitu interaksi yang terjadi dalam kelompok, terutama dalam hubungan keluarga tujuannya agar keluarga itu bisa terbina dengan baik. Dalam konteks itu, seorang anak harus mengerti dan mematuhi perintah yang disampaikan oleh orang tuanya, begitu pula sebaliknya orang tua harus memberikan ajaran yang baik kepada anaknya. Keluarga adalah tempat seorang anak, ibu, dan ayah saling berbagi (Rakhmawati, 2015).

Komunikasi yang sering terjadi dalam keluarga merupakan komunikasi interpersonal, karena dilakukan dalam kelompok kecil dan adanya umpan balik. Komunikasi interpersonal merupakan sebuah proses pengiriman dan penerimaan pesanpesan antara dua orang, atau di antara sekelompok kecil orang, dengan beberapa efek umpan balik seketika. Komunikasi dalam keluarga akan memberikan pengaruh yang positif jika yang terbentuk adalah komunikasi interpersonal yang efektif. Menurut Devito (1995), terdapat lima karakteristik komunikasi interpersonal yang efektif, yaitu keterbukaan, empati, sikap mendukung, sikap positif, dan kesetaraan. Jika komunikasi interpersonal dapat berlangsung secara efektif antara setiap anggota keluarga maka akan timbul sikap saling pengertian dan keharmonisan dalam keluarga. Komunikasi interpersonal merupakan proses komunikasi yang berlangsung antara dua orang atau lebih secara tatap muka. 
Melalui komunikasi interpersonal yang efektif, setiap anggota keluarga akan mampu menemukan dirinya sendiri, menemukan dunia luar, membentuk, dan menjaga hubungan yang penuh arti, mengubah sikap, dan tingkah laku untuk bermain dan kesenangan, serta untuk membantu (Muhammad, 2002). Sebaliknya, jika komunikasi interpersonal dalam keluarga tidak efektif, maka akan terjadi konflik, perpecahan, dan berbagai konflik lainnya dalam keluarga.

Di Kampung Cimpu, Kenagarian Surantih, Kecamatan Sutera, Kabupaten Pesisir Selatan yang pada umumnya dialami oleh orangorang yang sudah memiliki pekerjaan dan berpendidikan, perkembangan kenakalan remaja di Kampung Cimpu jelas terlihat sangat memprihatinkan, seperti masih ada remaja yang merokok, minum-minuman keras, sering keluar malam, ugalugalan di jalan raya, mencuri, berjudi, bahkan menjurus pada pergaulan bebas. Hal ini berdasarkan hasil wawancara dengan Wali Kampung Cimpu, Kenagarian Surantih, Kecamatan Sutera, Kabupaten Pesisir Selatan.

Sehubungan dengan hal tersebut, pada tanggal 25 Juli 2015 peneliti telah melakukan wawancara di Kampung Cimpu, Kecamatan Sutera Kenagarian Surantih Kabupaten Pesisir Selatan. Wawancara dilakukan kepada orang tua remaja, Ibu Een yang bekerja sebagai pedagang di Pasar Surantih. Ibu Een memiliki 3 orang anak lakilaki yang salah satunya duduk di bangku sekolah menengah atas dan memiliki perilaku yang kurang baik. Menurut tuturan beliau, anaknya sering membantah perintah orang tua, sering keluar malam. Sedangkan menurut laporan dari tetangga, anak Ibu Een ini suka mengendarai kendaraan dengan kecepatan tinggi di jalan raya.

Selanjutnya Ibu Nining yang bekerja sebagai petugas kebersihan di Puskesmas Surantih dan memiliki 1 orang anak laki-laki. anak beliau duduk di bangku sekolah menengah atas dan memiliki perilaku yang kurang baik. Menurut tuturan beliau, anaknya sering keluar malam tanpa sepengetahuan orang tuanya, merokok secara diam-diam, dan sering berkata kotor. Ibu Nining juga pernah mendapatkan surat peringatan dari sekolah yang mengatakan bahwa anak beliau sering tidak mengikuti Proses Belajar Mengajar (PBM), merokok di warung belakang sekolah, bahkan tertangkap melihat video orang dewasa.

Hal ini menimbulkan masalah bagi orang tua dalam menghadapi perilaku anakanaknya. Apabila fenomena ini tidak segera disikapi dengan cepat dan tepat dan remaja dibiarkan berkembang dengan sendiri tanpa arahan dan perhatian yang benar, maka pertumbuhan remaja menjadi tidak baik. Hal ini didukung dengan hasil observasi peneliti yang dilakukan pada tanggal 4 April 2015 di Kenagarian Surantih, Kabupaten Pesisir Selatan dan tuturan dari seorang guru di SMAN 1 Sutera Kenagarian Surantih bahwa masih banyak terlihat perilaku remaja yang memprihatinkan, meliputi anak sering bolos sekolah, tidak mengikuti Proses Belajar Mengajar (PBM) di kelas atau cabut tetapi lebih sering dudukduduk di warung sambil merokok, berjudi, sering keluar malam dan perilaku negatif lainnya bahkan menjurus pada pergaulan bebas.

Selain itu, peneliti juga melakukan wawancara dengan beberapa remaja pada tanggal 06 April 2015 di Kampung Cimpu, Kenagarian Surantih, Kecamatan Sutera, Kabupaten Pesisir Selatan salah satu bentuk kenakalan remaja yaitu banyak remaja yang meminumminuman keras di saat mereka mengikuti acara perayaan pergantian tahun maupun pesta pernikahan yang diadakan setiap akhir pekan, dan lain-lain. Setelah melakukan observasi, peneliti melakukan wawancara terhadap lima orang remaja yang berinisial DS, JA, FS, AP, 
dan FI, dari hasil wawancara tersebut ditemukan bahwa tiga orang dari remaja masih menjalani pendidikan sekolah menengah atas dan dua lainnya remaja putus sekolah.

Tujuan dalam penelitian ini adalah untuk mengetahui (a) gambaran komunikasi interpersonal orang tua dan remaja dalam keluarga di Kampung Cimpu, (b) gambaran kenakalan remaja di Kampung Cimpu, (c) melihat hubungan antara komunikasi interpersonal dalam keluarga dengan kenakalan remaja di Kampung Cimpu, Kenagarian Surantih, Kecamatan Sutera, Kabupaen Pesisir Selatan.

\section{METODE}

Penelitian ini merupakan penelitian kuantitatif jenis korelasional. Penelitian korelasional merupakan penelitian yang dimaksudkan untuk mengetahui ada tidaknya hubungan antara dua atau beberapa variabel. Dalam penelitian ini variabel yang akan diteliti yaitu komunikasi interpersonal sebagai variabel $(\mathrm{X})$ dan kenakalan remaja sebagai variabel (Y).

Populasi dalam penelitian ini adalah remaja yang nakal, yaitu siswa SMAN 1 Sutera kelas XI di Kampung Cimpu, Kenagarian Surantih, Kecamatan Sutera yang berjumlah 30 orang. Penulis memilih remaja tersebut berdasarkan pada keterangan dari narasumber yaitu guru BK yang mengajar di sekolah yang mengatakan bahwa para remaja tersebut bertingkah laku kurang baik dalam kesehariannya.

Jenis data yang diperlukan dalam penelitian ini adalah data yang diperoleh langsung dari responden berupa informasi tentang komunikasi interpersonal orang tua dengan remaja dalam keluarga dan kenakalan remaja di Kampung Cimpu, Kenagarian Surantih, Kecamatan Sutera, Kabupaten Pesisir Selatan. Adapun sumber data dalam penelitian ini adalah sebagian remaja di SMAN 1 Sutera yang dijadikan sampel berjumlah 30 orang. Untuk menggambarkan komunikasi interpersonal remaja dalam keluarga dan kenakalan remaja digunakan rumus teknik analisis persentase (\%). Selanjutnya untuk melihat hubungan antara variabel (x) dan variabel (y) menggunakan rumus stratifide product moment.

\section{HASIL PENELITIAN DAN PEMBAHASAN}

\section{Hasil Penelitian}

\section{Gambaran Komunikasi Interpersonal Remaja dalam Keluarga}

Berikut ini akan dijelaskan mengenai data hasil penelitian komunikasi interpersonal yang terdiri dari tiga aspek, antara lain adalah aspek keterbukaan, aspek empati, dan aspek sikap mendukung dari 30 orang remaja sebagai responden dan item sebanyak 26 pernyataan. Data dikelompokkan masing-masing berdasarkan nilai skor, dan dihitung persentasenya, maka dapat dibuat rangkuman distribusi frekuensi keterbukaan, empati, dan sikap mendukung orang tua dan anak dalam keluarga yang terlihat pada Gambar 1. berikut. 


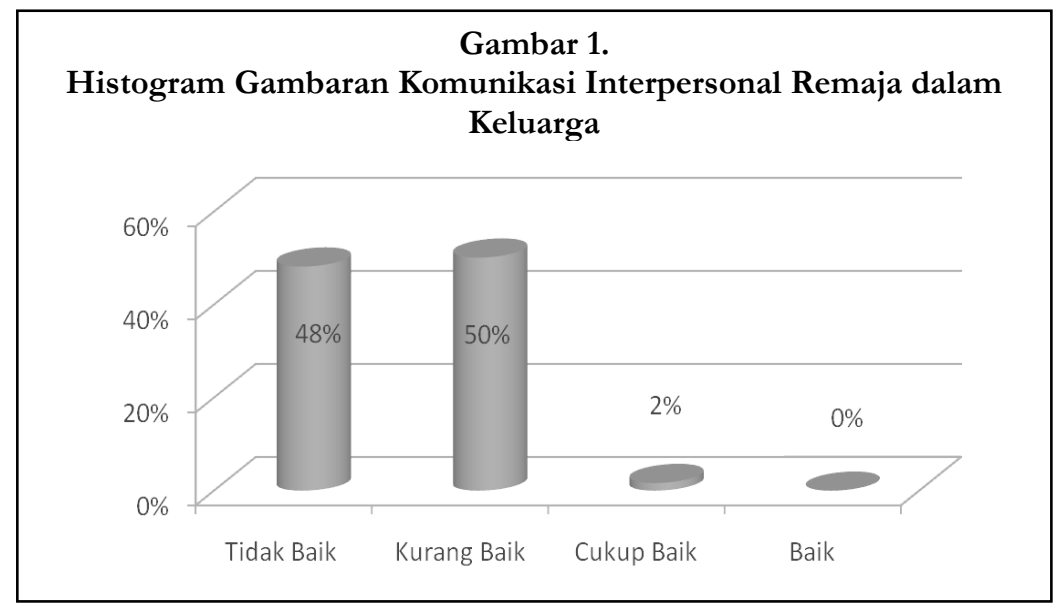

Berdasarkan gambar di atas dapat diketahui bahwa komunikasi interpersonal remaja dalam keluarga (48\%) responden dikategorikan tidak baik, (50\%) responden dikategorikan kurang baik, (2\%) dikategorikan cukup baik, dan (0\%) responden dikategorikan baik. Artinya komunikasi interpersonal yang terjadi antara orang tua dan remaja di Kampung Cimpu masih dikategorikan kurang baik. Hal ini dapat disebabkan oleh belum maksimalnya peranan orang tua dalam menciptakan situasi yang sehat dengan anak, yaitu kurangnya komunikasi yang penuh kasih sayang, persahabatan, kerja sama, penghargaan, kejujuran, kepercayaan, dan keterbukaan yang membentuk ketentraman dalam keluarga.

Ketidakefektifan hubungan antara orang tua dan anak dalam keluarga mengkibatkan timbulnya sikap negatif pada remaja, sehingga berdampak menjadikan pribadi remaja berperilaku nakal yang bisa dikatakan dengan kenakalan remaja. Hal ini terlihat dari jawaban responden yang mengindikasikan bahwa penerapan sikap keterbukaan, empati, dan sikap mendukung antara orang tua dan anak masih kurang baik.

\section{Gambaran Kenakalan Remaja di Kampung Cimpu Kenagarian Surantih}

Berikut ini akan dijelaskan mengenai data hasil penelitian kenakalan remaja yang terdiri dari tiga aspek antara lain pelanggaran, perkelahian, dan pergaulan bebas dari 30 orang remaja sebagai responden dan item keseluruhan sebanyak 19 pernyataan. Berdasarkan Gambar 2. dapat diketahui bahwa kenakalan remaja yang terjadi di Kampung Cimpu, Kenagarian Surantih menunjukkan 16\% responden merespon dengan respon yang dikategorikan sangat rendah, 25\% responden menyatakan rendah, 58\% menyata kan tinggi, dan $(2 \%)$ responden menyatakan sangat tinggi.

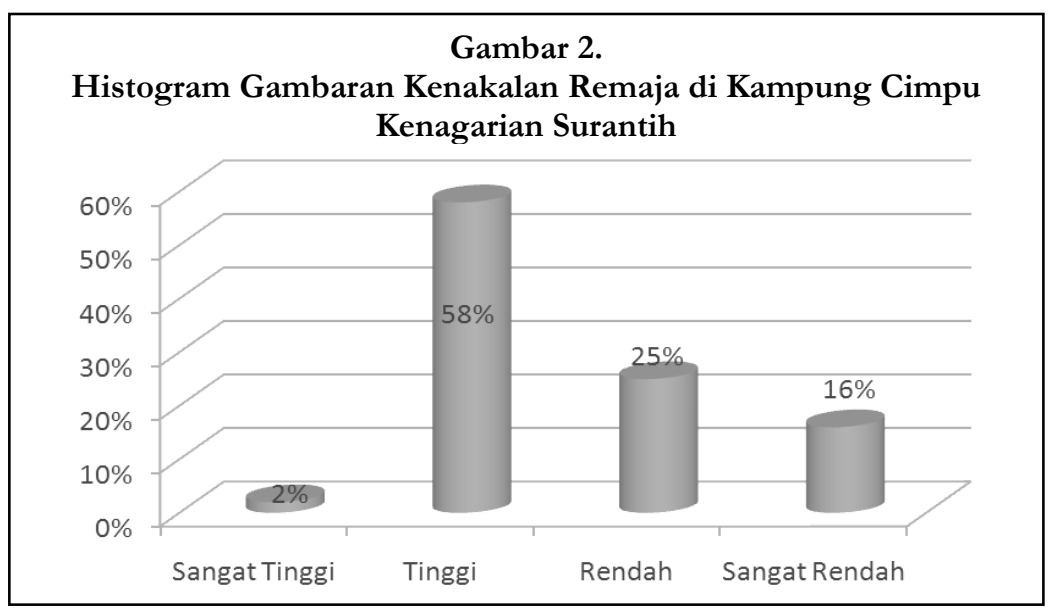


Dengan demikian dapat disimpulkan bahwa kenakalan remaja yang terjadi di Kampung Cimpu, Kenagarian Surantih seperti terlihat pada Gambar 2., dapat dikategorikan tinggi. Hal ini bisa terjadi karena keadaan keluarga yang dapat menjadikan sebab timbulnya kenakalan remaja, yaitu salah satunya berupa keluarga yang tidak normal (broken home) terutama perceraian atau perpisahan orang tua dapat memengaruhi perkembangan anak. Dalam keadaan ini, anak frustasi dan mengalami konflik-konflik psikologis, sehingga keadaan ini dapat mendorong anak menjadi nakal. Pendidikan dari lingkungan keluargalah yang menunjang remaja itu sendiri dalam menumbuhkan sikap positif dalam dirinya.

\section{Hubungan antara Komunikasi Interpersonal dalam Keluarga dengan Kenakalan Remaja}

Hipotesis yang diajukan dalam penenlitian ini adalah terdapat hubungan yang signifikan antara konsentrasi belajar peserta didik dengan keaktifan belajarnya pada bimbingan belajar bahasa Inggris Happy Course di Kecamatan Keliling Danau Kabupaten Kerinci. Salah satu tujuan penelitian ini adalah untuk melihat hubungan antara komunikasi interpersonal dalam keluarga dengan kenakalan remaja di Kampung Cimpu, Kenagarian Suranrantih, Kecamatan Sutera, Kabupaten Pesisir Selatan. Untuk mengumpulkan data tersebut, peneliti telah menyebarkan angket kepada remaja di SMA Negeri 1 Sutera Kabupaten Pesisir Selatan.

Berdasarkan analisis data di atas yang di uji dengan menggunakan rumus product moment didapat $r_{\text {hitung }}=0,969$ dan setelah dikonsultasikan dengan nilai $r_{\text {tabel }}=0,463$ dengan $\mathrm{n}$ $=30$ dan ${ }^{\alpha}=0,05$. Ternyata dapat dilihat bahwa $r_{\text {hitung }}>\mathrm{r}_{\text {tabel, }}$, baik tingkat kepercayaan $95 \%$ $(0,361)$ maupun tingkat kepercayaan $99 \%(0,463)$, yang berarti berarti terdapat hubungan yang signifikan antara komunikasi interpersonal dalam keluarga dengan kenakalan remaja. Maka hipotesis diterima. Dengan demikian dapat disimpulkan bahwa semakin baik komunikasi interpersonal dalam keluarga, maka tingkat kenakalan remaja semakin berkurang Sebaliknya semakin kurang baik komunikasi interpersonal dalam keluarga, maka tingkat kenakalan remaja semakin tinggi.

\section{Pembahasan}

\section{Gambaran Komunikasi Interpersonal Remaja dalam Keluarga}

Berdasarkan analisis data, temuan penelitian menunjukkan bahwa gambaran komunikasi interpersonal remaja dalam keluarga, diantaranya terdiri dari aspek keterbukaan, aspek empati, dan aspek sikap mendukung. Dalam hasil penelitian terlihat bahwa tabel distribusi frekuensi menunjukkan bahwa komunikasi interpersonal yang diterapkan di dalam keluarga para remaja tergolong rendah. Hal ini ditandai dengan sebagian besar responden menjawab pilihan jarang, artinya remaja yang berada di Kampung Cimpu, Kenagarian Surantih, Kecamatan Sutera Kabupaten, Pesisir Selatan dikategorikan memiliki kepribadian yang kurang baik dalam lingkungannya.

Komunikasi interpersonal dapat diartikan sebagai proses penyampaian berita yang dilakukan oleh seseorang dan diterimanya berita tersebut oleh orang lain atau kelompok kecil dari orang-orang, dengan suatu akibat dan umpan balik dengan segera. Selanjutya, Liliweri (1991) menyatakan bahwa komunikasi interpersonal merupakan komunikasi dari mulut ke mulut yang terjadi dalam interaksi tatap muka antara beberapa pribadi. 
Keterlibatan orang tua dalam keluarga sangat besar pengaruhnya dalam membentuk kepribadian dan juga dapat membentuk rasa percaya diri pada remaja. Orang tua adalah perantara bagi kehadiran anak di muka bumi yang pertama kali mengasuh, mengajar, dan mendidik anak. Apabila anak-anak mereka terlibat dalam kegiatan yang tidak baik, orang tua segera menghentikannya dengan cara memberikan pemahaman tentang bahaya yang dapat merugikan diri anak. Dengan begitu, anak-anak dapat belajar dan memahami pengalaman yang berasal dari orang tuanya sendiri (Rahayu, 2011).

Komunikasi interpersonal mempunyai peranan penting untuk membentuk kepribadian yang baik pada anak dan memberikan pengaruh positif dari orang tua terhadap anak. Jika komunikasi interpersonal dapat berlangsung secara efektif antar setiap anggota keluarga, maka akan timbul sikap saling pengertian dan keharmonisan dalam keluarga. Muhammad (2002) mengungkapkan bahwa melalui komunikasi interpersonal yang efektif, setiap anggota keluarga akan mampu menemukan diri sendiri, menemukan dunia luar, membentuk dan menjaga hubungan yang penuh arti, mengubah sikap dan tingkah laku untuk bermain dan kesenangan serta untuk membantu. Sebaliknya, jika komunikasi interpersonal dalam keluarga tidak efektif, maka akan terjadi konflik, perpecahan, dan berbagai konflik lainnya dalam keluarga.

Dari penjelasan di atas, dapat disimpulkan bahwa keefektifan komunikasi interpersonal dalam keluarga yakni dalam aspek keterbukaan, empati, dan sikap mendukung perlu dimaksimalkan dalam pembentukkan kepribadian anak. Hal ini menjadi benteng pada pribadi anak dalam pergaulan di masyarakat, sehingga orang tua tidak merasa takut dan cemas untuk melepas anak pada dunia luar nantinya.

\section{Gambaran Kenakalan Remaja}

Berdasarkan temuan penelitian dan hasil pengolahan data tentang gambaran kenakalan remaja yang dilihat dari aspek pelanggaran, aspek pekelahian, dan aspek pergaulan bebas, diperoleh data bahwa kenakalan remaja yang terjadi di Kampung Cimpu dikatakan cukup tinggi. Dalam hasil penelitian terlihat dari tabel distribusi frekuensi, menunjukkan bahwa kenakalan remaja dapat digolongkan cukup tinggi.

Bakolah Inpres No. 6/1971 Pedoman 8 dalam Willis (2008) mengungkapkan bahwa kenakalan remaja ialah kelainan tingkah laku, perbuatan atau tindakan remaja yang bersifat asosial, bahkan anti sosial yang melanggar normanorma sosial, agama, serta ketentuan hukum yang berlaku di masyarakat. Sedangkan Hurlock (dalam Nisya \& Sofiah, 2012), mengatakan bahwa kenakalan remaja bersumber dari moral yang sudah berbahaya atau beresiko. Menurutnya, kerusakan moral bersumber dari (1) Keluarga yang sibuk, keluarga yang retak, dan keluarga yang single parent, di mana anak hanya diasuh oleh ibu; (2) Menurunnya kewibawaan sekolah dalam mengawasi anak; dan (3) Peranan dalam bidang keagamaan tidak mampu menangani masalah moral.

Weiner (dalam Mantri, 2014) mengemukakan salah satu upaya untuk mendefinisikan penyimpangan peilaku remaja dalam arti kenakalan remaja, yaitu kenakalan remaja adalah tindakan oleh seseorang yang belum dewasa yang sengaja melanggar hukum dan diketahui oleh anak itu sendiri bahwa jika perbuatannya itu sempat diketahui oleh petugas hukum ia bisa dikenai hukuman.

Berdasarkan uraian di atas, dapat ditarik kesimpulan bahwa kenakalan remaja ialah tindakan/perbuatan sebagian para remaja yang bertentangan dengan hukum, agama, dan 
norma-norma masyarakat sehingga berakibat merugikan orang lain, mengganggu ketentraman umum, dan juga dapat merusak dirinya sendiri

\section{Hubungan Komunikasi Interpersonal dalam Keluarga dengan Kenakalan Remaja}

Berdasarkan hasil analisis data yang diperoleh, ditemukan bahwa terdapat hubungan yang signifikan antara kedua variabel. Hal ini terbukti dari hasil analisis data yang menunjukkan bahwa $\mathrm{r}_{\text {hitung }}>\mathrm{r}_{\text {tabel, }}$, itu berarti hipotesis diterima yang berarti terdapat hubungan yang signifikan antara komunikasi interpersonal dengan kenakalan remaja di Kampung Cimpu, Kenagarian Surantih, Kecamatan Sutera, Kabupaten Pesisir Selatan.

Pendidikan dalam keluarga akan selalu memengaruhi hubungan tumbuhnya watak, budi pekerti, dan kepribadian tiap-tiap manusia. Menurut Nayana (2013) bahwa semakin baik fungsi keluarga, maka semakin rendah tingkat kenakalan remaja. Sulaiman (dalam Widjaja, 2000) mengatakan bahwa komunikasi keluarga merupakan unsur yang berperan dalam pembentukkan kepribadian anggota keluarga khususnya anak. Kegiatan komunikasi keluarga yang baik dapat membentuk gaya hidup dalam keluarga yang sehat. Dampak situasi hubungan yang sehat antara orang tua dan anak, yaitu komunikasi yang penuh kasih sayang, persahabatan, kerja sama, penghargaan, kejujuran, kepercayaan, dan keterbukaan membentuk ketentraman keluarga. Dengan demikian dapat terlihat bahwa komunikasi interpersonal dalam keluarga sangat penting dalam mendidik anak remaja (Sumakul, 2015).

Komunikasi interpersonal orang tua terhadap remaja akan menentukan apakah pendidikan keluarga dapat berjalan dengan baik untuk memberikan pengawasan, bimbingan, dan arahan kepada remaja. Menurut Widjaja (2000), komunikasi yang berkualitas adalah komunikasi yang dilandasi dengan adanya kepercayaan, keterbukaan, dan dukungan yang positif pada anak, agar anak dapat menerima dengan baik apa yang disampaikan oleh orang tua.

Rex Forenhand (dalam Sarwono, 2005) mengemukakan bahwa semakin tinggi tingkat pemantauan orang tua terhadap anak remajanya, semakin rendah kemungkinan perilaku menyimpang menimpa seorang remaja. Maka dari itu, di samping komunikasi yang baik dengan anak, orang tua juga perlu mengembangkan kepercayaan pada anak dengan berkomunikasi secara pribadi, sehingga anak memiliki pegangan dalam menjalani kehidupannya kelak dengan bekal yang telah ia miliki dari kedua orang tuanya.

Sillars \& Scott (dalam Liliweri, 1991) mengemukaan pendapat mereka bahwa hubungan antarpribadi yang intim disebabkan oleh interaksi yang berulang-ulang dengan derajat kebebasan dan keterbukaan yang sangat tinggi. Derajat keterbukaan tersebut mempunyai pangaruh untuk mengubah pikiran, perasaan maupun perilaku orang lain. Komunikasi interpersonal dalam penelitian ini terdiri dari aspek keterbukaan, aspek empati, dan aspek sikap mendukung. Ketiga aspek tersebut mempengaruhi kepribadian remaja dalam lingkungan masyarakat. Karena komunikasi interpesonal tidak diterapkan dengan baik mengakibatkan kenakalan remaja semakin tinggi.

\section{KESIMPULAN}

Berdasarkan hasil analisis data yang diperoleh, ditemukan bahwa terdapat hubungan yang signifikan antara kedua variabel. Hal ini terbukti dari hasil analisis data yang 


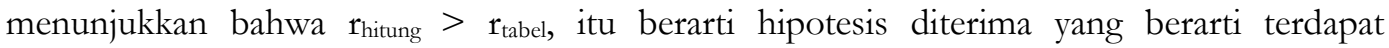
hubungan yang signifikan antara komunikasi interpersonal dengan kenakalan remaja di Kampung Cimpu, Kenagarian Surantih, Kecamatan Sutera, Kabupaten Pesisir Selatan.

Pendidikan dalam keluarga akan selalu memengaruhi hubungan tumbuhnya watak, budi pekerti, dan kepribadian tiap-tiap manusia. Menurut Nayana (2013) bahwa semakin baik fungsi keluarga, maka semakin rendah tingkat kenakalan remaja. Sulaiman (dalam Widjaja, 2000), mengatakan bahwa komunikasi keluarga merupakan unsur yang berperan dalam pembentukkan kepribadian anggota keluarga khususnya anak. Kegiatan komunikasi keluarga yang baik dapat membentuk gaya hidup dalam keluarga yang sehat. Dampak situasi hubungan yang sehat antara orang tua dan anak, yaitu komunikasi yang penuh kasih sayang, persahabatan, kerja sama, penghargaan, kejujuran, kepercayaan, dan keterbukaan membentuk ketentraman keluarga. Dengan demikian dapat terlihat bahwa komunikasi interpersonal dalam keluarga sangat penting dalam mendidik anak remaja.

\section{DAFTAR RUJUKAN}

Devito, J. A. (1995). Komunikasi Antar Manusia. Jakarta: Profesional Book.

Liliweri, A. (1991). Komunikasi Antarpribadi. Bandung: Citra Aditya Bakti.

Mantri, V. V. (2014). Perilaku Menyimpang di Kalangan Remaja di Kelurahan Pondang, Kecamatan Amurang Timur Kabupaten Minahasa Selatan, III(1), $1-13$.

Mariska, G. (2014). Proses Komunikasi Orang Tua-Anak pada Keluarga dengan Ibu Bekerja dan Ayah sebagai Ayah Rumah Tangga. Jurnal E-Komunikasi, 2(1).

Muhammad, A. (2002). Komunikasi Organisasi. Jakarta: Bumi Aksara.

Nayana, F. N. (2013). Kefungsian Keluarga dan Subjective Well-Being pada Remaja. Jurnal Ilmiah Psikologi Terapan, 01(02), 230-244.

Nisya, L. S., \& Sofiah, D. (2012). Religiusitas, Kecerdasan Emosional dan Kenakalan Remaja. Jurnal Psikologi Tabularasa, 7(2), 562-584.

Rahayu, W. P. (2011). Analisis Intensitas Pendidikan oleh Orang Tua dalam Kegiatan Belajar Anak, Status Sosial Ekonomi Orang Tua terhadap Motivasi Belajar dan Prestasi Belajar Siswa. Jurnal Pendidikan Dan Pembelajaran, 18(1), 72-80.

Rakhmawati, I. (2015). Peran Keluarga dalam Pengasuhan Anak. KONSELING RELIGI: Jurnal Bimbingan Konseling Islam, 6(1), 1-18. https://doi.org/10.21043/kr.v6i1.1037

Sarwono, S. W. (2005). Psikologi Remaja. Jakarta: PT. Raja Grafindo Persada.

Sumakul, B. J. (2015). Peranan Komunikasi Keluarga dalam Pembentukan Identitas Remaja di Kelurahan Malalayang I Kecamatan Malalayang Kota Manado. EJournal "Acta Diurna", IV(4).

Walgito, B. (2004). Bimbingan \& Konseling di Sekolah. Yogyakarta: Andi Offset.

Wardyaningrum, D. (2013). Komunikasi untuk Penyelesaian Konflik dalam

Keluarga: Orientasi Percakapan dan Orientasi Kepatuhan. Jurnal Al-Azhar

Indonesia Seri Pranata Sosial, 2(1), 47-58.

Widjaja, H. A. . (2000). Ilmu Komunikasi Pengantar Studi. Jakarta: Rineka Cipta.

Willis, S. S. (2008). Remaja \& Masalabnya. Bandung: Alfabeta. 